University of Nebraska - Lincoln

DigitalCommons@University of Nebraska - Lincoln

Agronomy \& Horticulture -- Faculty Publications

Agronomy and Horticulture Department

1958

\title{
Soil aggregation by microorganisms following soil fumigation
}

T. M. McCalla

United States Department of Agriculture

Francis A. Haskins

University of Nebraska-Lincoln, fhaskins@neb.rr.com

R. D. Curley

University of Nebraska-Lincoln

Follow this and additional works at: https://digitalcommons.unl.edu/agronomyfacpub

Part of the Plant Sciences Commons

McCalla, T. M.; Haskins, Francis A.; and Curley, R. D., "Soil aggregation by microorganisms following soil fumigation" (1958). Agronomy \& Horticulture -- Faculty Publications. 311.

https://digitalcommons.unl.edu/agronomyfacpub/311

This Article is brought to you for free and open access by the Agronomy and Horticulture Department at DigitalCommons@University of Nebraska - Lincoln. It has been accepted for inclusion in Agronomy \& Horticulture -Faculty Publications by an authorized administrator of DigitalCommons@University of Nebraska - Lincoln. 


\title{
Soil Aggregation by Microorganisms Following Soil Fumigation ${ }^{1}$
}

\author{
T. M. McCalla, F. A. Haskins, and R. D. CuRley ${ }^{2}$
}

\begin{abstract}
The influence of autoclaving and of fumigation with eight chemical formulations upon microbial numbers in straw-amended Peorian loess and the extent to which these treatments affect the degree of aggregation brought about by subsequently introduced inocula were determined. A mixed soil flora, Stachybotrys atra and a blank inoculum consisting of sterile salt solution, were compared. Only in the autoclaved soil was a mixed soil flora inoculum consistently superior to the blank inoculum in promoting aggregation of the Peorian loess. It was found that inoculation with $S$. atra could greatly increase the aggregation of fumigated Peorian loess in treatments where the fumigation was effective in reducing microbial numbers to a low level, and where the fumigant exerted little if any residual toxic effect upon the $S$. atra inoculum. Most promising of the fumigants tested were chloropicrin and Telone. The aggregation brought about by inoculation with $S$, atra in Peorian loess fumigated by appropriate amounts of either of these chemicals was approximately
\end{abstract}

'Contribution by the Soil \& Water Conservation Research Division, ARS, USDA, and the Department of Agronomy, Nebraska Agr. Exp. Sta., Lincoln, cooperating. Published with the approval of the Director as Paper No. 851, Journal Series, Nebraska Agr. Exp. Sta. Presented before Div. III, Soil Science Society of America, Nov. 20, 1957, at Atlanta, Ga. Received Dec. 12, 1957. Approved April 8, 1958.

${ }^{2}$ Bacteriologist, Soil \& Water Conservation Research Division, ARS, USDA; and Associate Professor of Agronomy and former Graduate Student, Univ. of Nebraska, respectively. two-thirds as high as that produced by the same organism following autoclaving of the soil material.

Soll structure influences water intake, soil aeration, $S$ and degree of erosion by wind and water and thereby affects the growth of microorganisms as well as higher plants. The structural status of a soil is the net result of many complex reactions involving physical, chemical, and biological agents. Among the biological agents, microorganisms are of great importance in soil structure stabilization. Microorganisms, during decomposition of plant and animal residues, produce numerous organic compounds and release inorganic substances, both of which may affect stability of the soil units in various ways (7). Some of the compounds produced and released exert a tremendous effect on stability, while other compounds have only a slight effect or no effect at all. Some of the natural products produced by microorganisms are more effective per unit weight than are the synthetic stabilizers $(2,9)$. Microorganisms vary greatly in their ability to stabilize the soil (8). Some, such as the cellulose decomposer Stachybotrys atra, are highly effective in increasing soil aggregation $(3,4)$.

Previous experience has shown that before an organism such as $S$. atra can be used as an aggregator, it is necessary that the natural microflora be reduced to a low point. This reduction can be accomplished by heat treatment, such as autoclaving. Soil fumigation to combat plant pathogens is becoming an increasingly common agronomic practice $(5,10)$. The chemicals may kill saprophytic 
as well as pathogenic organisms (6). Such treatments may open the way for the establishment, through artificial inoculation, of microorganisms with high aggregating ability. This paper deals with laboratory experiments which were undertaken in an effort to determine the influence of certain soil fumigants upon microbial numbers in the soil, and the effectiveness of various inocula in promoting aggregation of the fumigated soil.

\section{EXPERIMENTAL PROCEDURE}

Soil material.-Peorian loess was obtained from a road cut near Plattsmouth, Nebraska at a depth of 10 to 20 feet. This material is very low in organic matter (less than $0.5 \%$ ) and in water-stable aggregates larger than $0.2 \mathrm{~mm}$. (approximately $2 \%$ ). After being held for 1 week at room temperature with a moisture content of $20 \%$, the Peorian loess contained approximately 20,000 fungi and $3,000,000$ bacteria and actinomycetes per g. of soil material. Moisture percentages of this soil material at $1 / 3$ and $15 \mathrm{~atm}$. tension are 21.3 and $8.0 \%$ respectively. All Peorian loess was screened through a $2-\mathrm{mm}$. sieve prior to use.

Inocula-Stachybotrys atra was maintained on slants of potato-dextrose agar. Inocula for the aggregation experiments were prepared by suspending the growth from these slants in sterile portions of the salt solution defined below. The "soil flora" inoculum was prepared by suspending a pinch of topsoil in the salt solution. Sterile salt solution alone was used as a blank inoculum. Composition of the salt solution was:

$\begin{array}{ll}\mathrm{NH}_{4} \mathrm{NO}_{3} & 8 \mathrm{~g} . \\ \mathrm{K}_{2} \mathrm{HPO}_{4} & 4 \mathrm{~g} . \\ \mathrm{MgSO}_{4} \cdot 7 \mathrm{H}_{2} \mathrm{O} & 2 \mathrm{~g} . \\ \mathrm{FeSO}_{4} & <0.1 \mathrm{~g} . \\ \text { Water (tap) } & 1,000 \mathrm{ml} .\end{array}$

Chemicals.-Eight chemicals and chemical formulations were used for fumigation. Biuret-urea-formaldehyde (biureturea $26.46 \%$ and formaldehyde $48.65 \%$ ), UF-85 (formaldehyde $59 \%$ and urea $26 \%$ ), and carbon disulfide (reagent grade) were supplied by Allied Chemical and Dye Corporation. Water emulsifiable pentachlorophenol (containing 4 pounds of pentachlorophenol per gallon), Garden Dowfume or W-40 (ethylene dibromide $41 \%$ ), and Telone (chlorinated $C_{5}$ hydrocarbons $100 \%$ ) were furnished by Dow Chemical Company. Chloropicrin and ethylene oxide were obtained from Eastman Kodak Company.

Fumigation.-The following procedure was used for each of the eight fumigants: Water was added to approximately $9 \mathrm{~kg}$. of screened Peorian loess to give a moisture content of $20 \%$, and the material was thoroughly mixed. Sixteen 500-g. portions (oven-dry basis) of the soil material were then transferred to individual sterile 1-liter beakers. Beakers which were to have fumigation treatments received the fumigant immediately before the soil material was placed in the beaker. Immediately following addition of the soil material a seal of $40 \mathrm{ml}$. of sterile water was added to the surface. Duplicate beakers received the following levels of fumigant: $0.1,0.25$, $0.5,1.0,2.0$ and $4.0 \mathrm{ml}$. Two of the remaining four beakers were used as the nontreated controls and two furnished material at the end of the fumigation period for autoclaved controls. Control beakers also received the $40-\mathrm{ml}$. water seal. Each beaker was covered with wrapping paper held in place by a rubber band. Beakers were kept in a fume hood for 7 days following initiation of the treatments.

Determinations of effects on aggregation and microbial numbers.-After the fumigation period, nine $35-\mathrm{g}$. portions of the thoroughly mixed contents of each beaker were transferred to individual sterile petri plates. Beakers were also sampled for moisture determinations at this time, and were then held at $4^{\circ}$ C. (usually about 1 or 2 days) until samples could be taken for plate counts. A $0.35-\mathrm{g}$. portion of sterile ground wheat straw was mixed with the contents of each petri plate. Autoclaved controls were exposed for 1 hour to steam at 15 psi. after addition of the straw. Triplicate plates were then inoculated with each of the three inocula previously described. Prior to inoculation, inocula were mixed with water in such a ratio as to give each plate the equivalent of $3.5 \mathrm{ml}$. of salt solution and a final moisture content of approximately $30 \%$. plates were incubated at $24^{\circ} \mathrm{C}$. for 2 weeks in a randomized block design. The extent of aggregation was then determined on two 10-g. samples of material from each plate as described by Downs et al. (3).

The influence of the treatments upon microbial numbers was determined by plating dilution series from each beaker on soil extract agar for total counts and on rose bengal agar for counts of fungi (1).

\section{RESULTS AND DISCUSSION}

Analytical results are shown in figures 1 to 8 , each graph representing the results obtained with one of the chemical formulations. In the aggregation data, each point represents the mean of 12 determinations (two determinations from each of three plates from each of 2 beakers). From the results with autoclaving, which reduced the microbial population essentially to zero, it can be seen that subsequent introduction of S. atra inoculum, soil flora, and blank inoculum resulted in aggregations of approximately 50,15 and $3 \%$, respectively. In the nontreated controls, aggregations of around 5 to $10 \%$ were achieved regardless of the inoculum used. These results demonstrate the low degree of aggregation in sterile Peorian loess and emphasize the inability of $S$. atra inoculation to bring about any marked increase in aggregation unless the bacterial and fungal populations are reduced.

Apparently this reduction in native microflora must be quite drastic before inoculation with $S$. atra can produce substantial aggregation. Thus, low levels of chloropicrin (figure 1) produced marked reductions in microflora, but the degree of aggregation brought about by subsequently introduced S. atra was still increasing somewhat at the highest level of fumigant which was used. At this level the degree of aggregation produced by inoculation with $S$. atra was approximately two-thirds of that which was attained following autoclaving. Ethylene oxide (figure 2) effected a considerable reduction in microbial numbers, but the reduction was not sufficient to permit an improvement of aggregation following inoculation with $S$. atra. In other experiments, plating at the end of the incubation period indicated that $S$. atra was not able to establish itself as the dominant organism. Telone (figure 3) was very effective in reducing the fungal population, but it was effective against bacteria only at the highest level tested. In the Telone experiment, depletion of the fungal population permitted an appreciable increase in aggregation after inoculation with $S$. atra, but highest aggregations were attained only after the bacterial population was also largely depleted. Pentachlorophenol (figure 4) was quite effective in reducing microbial numbers, but either through a direct effect on the soil material or through a residual toxicity to the inocula, this fumigant produced an unfavorable effect on aggregation. In other experiments, the soil was found to be essentially sterile after the incubation period. Carbon disulfide (figure 5) and $\mathrm{W}-40$ (figure 6) were not consistently effective in depleting the microflora, and aggregations following treatment of the soil material with these chemicals were uniformly low. The urea-formaldehyde (figure 7) and biureturea-formaldehyde (figure 8) treatments resulted in good kills of bacteria and fungi. Similar aggregation patterns were produced following inoculation of the fumigated soil material; that is, aggregation was relatively high at the $0.25-\mathrm{ml}$. or $0.5-\mathrm{ml}$. rate, but lower for other rates. Since very similar results were obtained for the three types of inoculum, it appears probable that the aggregations noted resulted directly from the chemical treatments and did not involve microbial activity. Why the effect was not noted at levels of fumigant above $0.5 \mathrm{ml}$. is not understood. These higher levels probably had a residual toxic effect upon the soil fora and S. atra inocula since the odor of formaldehyde was easily detected at the time of inoculation and also following incubation of the plates. In other experi- 

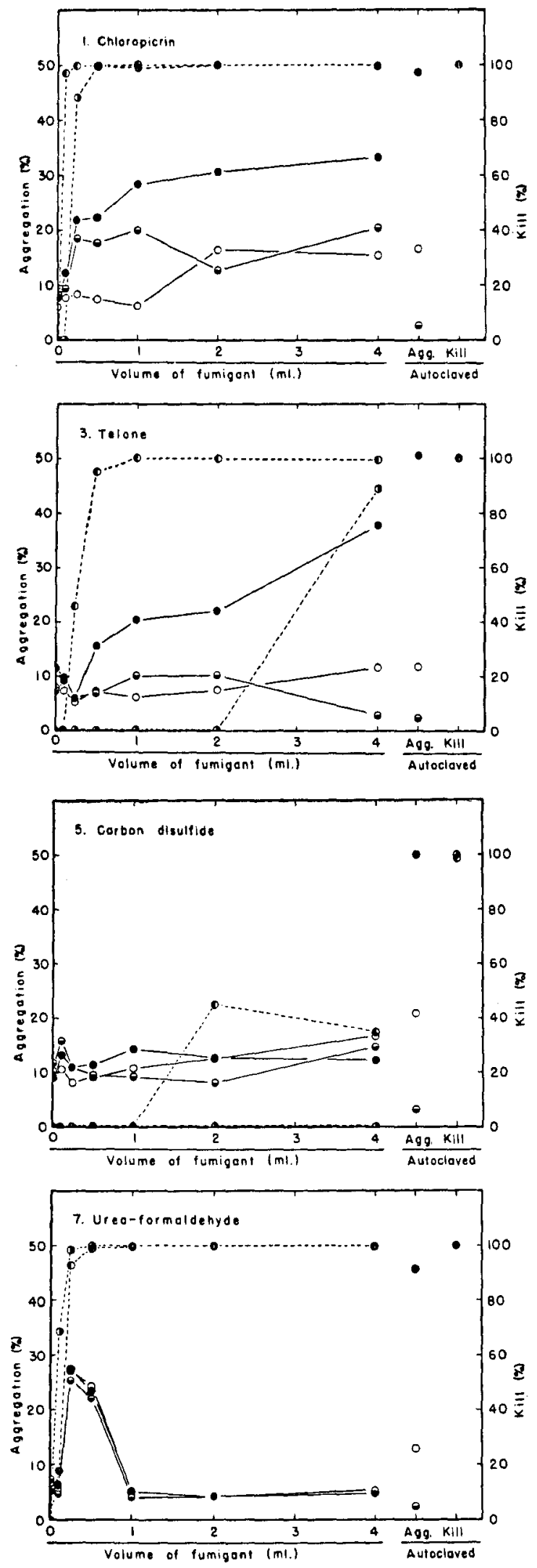

Aggregation:

Figures 1 to 8-The effect of different amounts of 8 fumigan ts upon numbers of microorganisms in Peoria loess and upon subsequent aggregation of the loess by 3 inocula.
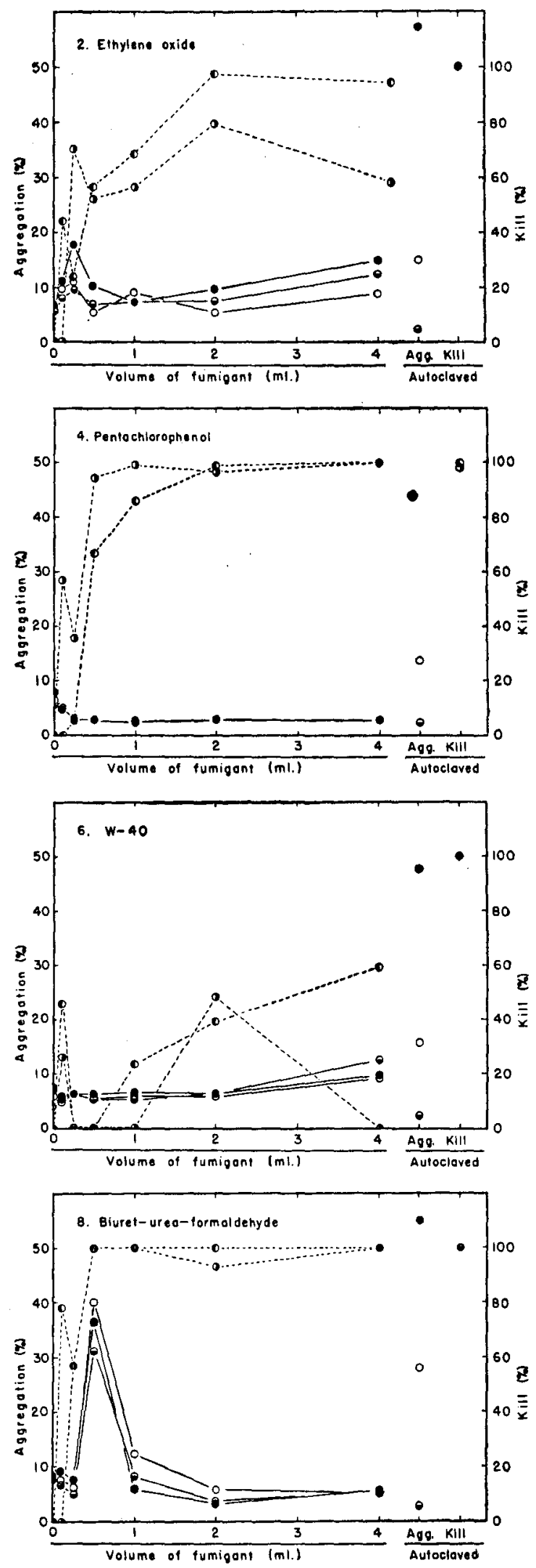

S. atra Kill: 0---0 Total; 0---0 Fungi 
ments, plating after the incubation period indicated that microbial activity was not involved.

In none of the fumigation treatments was the aggregation attained in the soil flora plates consistently higher than that found in the blank inoculum plates. All such plates (except those included in the urea-formaldehyde and biuret-urea-formaldehyde experiments) were low in degree of aggregation. Apparently neither the complex microflora of a pinch of topsoil, nor the microflora remaining in Peorian loess after fumigation treatments, are capable of effecting appreciable increases in soil aggregation following fumigation. However, following fumigation with Telone or chloropicrin and inoculation with S. atra, considerable aggregation occurred.

If acceptable aggregation of fumigated soils is to be achieved following inoculation by a microorganism such as S. atra, it is essential that the fumigant used be broad in spectrum and highly efficient in reducing the indigenous microflora. It is also necessary that the fumigant leave little if any permanently toxic residue in the soil.

\section{LITERATURE CITED}

1. Allen, O. N. Experiments in Soil Bacteriology. Burgess Publishing Co., Minneapolis, Minn. 1949.
2. Chesters, G., Attoe, O. J., and Allen, O. N. Soil aggregation in relation to various soil constituents. Soil Sci. Soc. Amer. Proc. 21:272-277. 1957.

3. Downs, S. C., McCalla, T. M. and Haskins, F. A. Stachybotrys atra, an effective aggregator of Peorian loess. Soil Sci. Soc. Amer. Proc. 19:179-181. 1955.

4. Jermyn, M. A. Fungal cellulases III. Stachybotrys atra: Growth and enzyme production on non-cellulosic substrates. Australian Jour. Biol. Sci. 6:48-69. 1953.

5. Lawrence, IV. J. C. Soil Sterilization. The MacMillan Co., New York. 1956.

6. Martin, J. P., Klotz, L. J., DeWolfe, T. A., and Ervin, J. $O$. Influence of some common soil fungi on growth of citrus seedlings. Soil Sci. 81:259-267. 1956.

7. McCalla, T. M. Influence of microorganisms and some organic substances on soil structure. Soil Sci. 59:287-297. 1945.

8. - Influence of some microbial groups on stabilizing soil structure against falling water drops. Soil Sci. Soc. Amer. Proc. (1946) 11:260-263. 1947.

9. Renne, D. A., Truog, Emil, and Allen, O. N. Soil aggregation as influenced by microbial gums, level of fertility and kind of crop. Soil Sci. Soc. Amer. Proc. 18:399-403. 1954.

10. Warcup, J. H. Chemical and biological aspects of soil sterilization. Soils and Fertilizers 20:1-5. 1957. 